\title{
Infecção experimental em camundongos neonatos com esporozoítas de Cystoisospora felis (Wenyon, 1923) Frenkel, 1977 (Apicomplexa: cystoisosporinae)
}

\author{
(Experimental infection in neonate mice with Cystoisospora felis (Wenyon, 1923) \\ Frenkel, 1977 (Apicomplexa: Cystoisosporinae) sporozoites)
}

\author{
Ronald Bastos Freire* e Carlos Wilson Gomes Lopes**
}

\begin{abstract}
Resumo
A habilidade de esporozoítas de Cystoisospora felis em infectar camundongos neonatos foi estudada. Mil esporozoítas foram inoculados intraperitonealmente em camundongos de 3 dias de idade. A resistência dos neonatos à infecção por $C$. felis foi acompanhada durante 12 dias a partir da inoculação. Macrófagos peritoniais obtidos a partir de adultos previamente infectados com esporozoítas deste parasita, foram também inoculados em neonatos pela mesma via. Não se observou, em nenhum dos casos, resistência de indivíduos neonatos a $C$. felis.
\end{abstract}

Palavras chave: Camundongos neonatos, Cystoisospora felis, esporozótas.

\section{Introdução}

A cistoisosporose é uma doença espoliativa, capaz de afetar o gato e camundongos, além de outros hospedeiros potenciais (Brösigke et al. 1982, Loss, 1991). Embora os efeitos da infecção por Cystoisospora rivolta tenham sido amplamente estudados (Brösigke, 1981), não se avaliou os efeitos do parasitismo de espécies deste gênero em neonatos.

Uma vez que as infecções por C. felis e C. rivolta têm apresentado tendência à cronicidade em indivíduos adultos (Fayer, 1980; Brösigke, 1981) espera-se que efeitos mais significativos se manifestem em neonatos e imunocomprometidos, a exemplo do que tem ocorrido em parasitoses por outros coccídios (Harp \& Whitmire, 1991).

Um lote de 14 camundongos neonatos foi inoculado por via intraperitonial com $10^{3}$ esporozoítas de C. felis, obtidos segundo metodologia descrita por Burgess et al. (1988), para Sarcocystis cruzi. Da mesma forma, 12 neonatos foram inoculados com lavado peritoneal oriundo de 3 camundongos adultos préviamente infectados com $10^{5}$ esporozoítas de C. felis, de acordo com metodologia descrita por Goyal et al. (1988). Ao mesmo tempo, dois sistemas de controle experimental, cada um deles contendo cinco camundongos neonatos, foram utilizados. O primeiro foi inoculado com o mesmo veículo empregado para obtenção da suspensão de esporozoítas e o segundo, com lavado peritonial obtido a partir de 3 adultos. não infectados

Todos os camundongos neonatos inoculados com esporozoítas, ou macrófagos contendo formas intracelulares de C. felis morreram, indicando haver uma ação lesiva deste protozoário sobre os animais, como sugeriu Loss (1991). Os animais inoculados com lavado peritonial faleceram entre o sétimo e o décimo segundo dia após a inoculação. Nenhum efeito deletério foi visualizado nos animais controles (Tabela 1). Necrópsia e digestão enzimática (Sharma \& Dubey, 1981) das vísceras foram feitas, onde se encontrou hipnozoítas de C. felis. Estas formas foram encontradas com mais freqüência no fígado dos neonatos.

A maior sobrevida, dos animais que receberam lavado peritoneal, sugeriu uma possível transferência de imunidade a partir dos adultos, uma vez que, juntamente com os fagócitos, outras células e mediadores poderiam ser transferidos (Harp \& Whitmire, 1991).

Uma vez que infecções experimentais em animais adultos de diferentes espécies (bovinos, cães, roedores e felinos) não determinam sua morte, pode-se afirmar que a morte dos neonatos inoculados representou um importante dado sobre a cistoisosporose, reforçando a possível ação deletérea sobre espécies animais passíveis de se infectar com C. felis. 
Tabela 1 - Sobrevida de camundongos neonatos à inoculação de 103 esporozoítas de Cystoisospora felis ou 106 fagócitos peritoneais oriundos de camundongos adultos previamente inoculados com 103 esporozoítas

\begin{tabular}{|c|c|c|c|c|c|c|c|c|}
\hline \multirow{2}{*}{ Inóculo } & \multirow{2}{*}{$\begin{array}{l}\text { Número de } \\
\text { animais }\end{array}$} & \multicolumn{7}{|c|}{ Taxa de sobrevida/dias após inoculação (\%) } \\
\hline & & 1 & 3 & 4 & 7 & 9 & 11 & 12 \\
\hline $\begin{array}{l}\text { Esporozoítas } \\
\text { Livres }\end{array}$ & 14 & 80 & 50 & 0 & ND & ND & ND & ND \\
\hline $\begin{array}{l}\text { Lavado } \\
\text { peritoneal }\end{array}$ & 12 & 100 & 100 & 100 & 83 & 60 & 50 & 0 \\
\hline Controles $^{b}$ & 10 & 100 & 100 & 100 & 100 & 100 & 100 & 100 \\
\hline
\end{tabular}

$\mathrm{ND}=$ Não determinado.

${ }^{\mathrm{b}}$ cinco camundongos inoculados com a suspensão líquida sem esporozoítas e mais cinco com lavado peritoneal sem esporozoítas.

\section{Abstract \\ Experimental infection in neonate mice with Cystoisospora felis (Wenyon, 1923) Frenkel, 1977 (Apicomplexa: Cystoisosporinae) sporozoites}

The ability of sporozoites of Cystoisospora felis to infect neonate mice was tested. One thousand sporozoites were inoculated intraperitoneally in neonate mice, and the resistence to $C$. felis was observed for a period of 12 days after infection. No resistance was observed to C. felis, when macrophages obtained from adult mice, infected previously with sporozoites, were transferred to these animals by intraperitoneal inoculation.

Key words: Cystoisospora felis, neonate mice, sporozoites.

\section{Referências}

BRÖSIGKE, S. Untersuchungen an Extraintestinallen Entwicklungstadien (Dormozoiten) von Cystoisospora rivolta der Katzen in der Maus. Muche, 37p., 1981. Dissertation zur Erlangung der Tiermedizinischen Doktor wurde der Tierarstlichen.
BRÖSIGKE, S., HEINE, J., BOCH., J. Der Nachweis Extraintestinallen Entwicklungstadien (Dormozoiten) in Experimental mit Cystoisospora rivolta Oozysten Infizierten Mausen. Kleiter Praxis v. 27, p. 2425, 1982

BURGESS, D.E., SPEER, C.A., REDUKER, D.W. Identification of Antigens of Sarcocystis cruzi Sporozoites, and Bradizoites with Monoclonal Antibodies. J. Parasitol., v.74, p. 828-832, 1988.

FAYER, R. Epidemiology of Protozoan Infection: The Coccidia. Vet. Parasitol., V. 6, p. 73-103, 1980.

GOYAL, M., GANGULY, N.K., MAHAJAN, R.C. Cytotoxic activity of Monocytes Against Toxoplasma gondii in Acute and Reactivated Murine Toxoplasmosis. Med. Microbiol. Immunol., v. 177, p. 339248, 1988.

HARP, J.A., WHITMIRE, W.M. Cryptosporidium parvum infection in mice: Inability of Lynphoid cells supernatants to transfer protection from resistant adults to susceptible infants. J. Parasitol., v. 77, p. 170-172, 1991.

LOSS, Z.G. Cistoisosporose Felina. Itaguaí, 1991. 104p. Tese (Doutorado em Parasitologia Animal) Universidade Federal Rural do Rio de Janeiro.

SHARMA, S.P., DUBEY, J.P. Quantitative Survival of Toxoplasma gondii Tachyzoites and Bradyzoites in Pepsin and Trypsin Solutions. Am. J. vet. Res., v. 42, p. 128-130, 1981. 